\begin{tabular}{|l|l|l||}
\hline \multicolumn{2}{|c|}{ PublisherInfo } \\
\hline \hline PublisherName & $:$ & BioMed Central \\
\hline \hline PublisherLocation & $:$ & London \\
\hline \hline PublisherImprintName & $:$ & BioMed Central \\
\hline \hline
\end{tabular}

\title{
Microarrays for secreted proteins
}

\begin{tabular}{|l|l|l||}
\hline \multicolumn{2}{|c|}{ ArticleInfo } \\
\hline \hline ArticleID & $:$ & 3673 \\
\hline \hline ArticleDOI & $:$ & $10.1186 /$ gb-spotlight-20000428-02 \\
\hline \hline ArticleCitationID & $:$ & spotlight-20000428-02 \\
\hline \hline ArticleSequenceNumber & $:$ & 110 \\
\hline \hline ArticleCategory & $:$ & Research news \\
\hline ArticleFirstPage & $:$ & 1 \\
\hline \hline ArticleLastPage & $:$ & 2 \\
\hline \hline & & RegistrationDate : 2000-04-28 \\
ArticleHistory & $:$ & OnlineDate $\quad$ 2000-04-28 \\
\hline \hline ArticleCopyright & $:$ & BioMed Central Ltd2000 \\
\hline \hline ArticleGrants & $:$ & \\
\hline \hline ArticleContext & $:$ & 130591111 \\
\hline \hline
\end{tabular}




\section{William Wells}

Email: wells@biotext.com

Secreted and membrane-associated proteins are important drug targets, but algorithms for recognizing the corresponding genes are imperfect, especially when the entire coding sequence is not available. Diehn et al. report in the May Nature Genetics that these proteins can be catalogued in two easy steps (Nature Genet. 2000, 25:58-62). Diehn et al. isolate membrane-bound mRNAs (attached to polysomes) and cytosolic mRNAs, followed by hybridization of the corresponding cDNAs to DNA microarrays. The majority of the known mRNAs that are enriched in the membrane fraction encode for secreted or membrane-bound proteins. Based on this correspondence, Diehn et al. claim to have identified over 275 human genes and 285 yeast genes that are likely to encode previously unrecognized secreted or membrane proteins.

\section{References}

1. Nature, [http://www.nature.com/ng/] 